European journal of American studies

Special Issue: Harriet Prescott Spofford: The Home, the Nation, and the Wilderness

\title{
Feline Alter Egos in Harriet Prescott Spofford's "Circumstance" and the Poetry of Emily Dickinson
}

Adeline Chevrier-Bosseau

\section{OpenEdition}

\section{Journals}

Electronic version

URL: https://journals.openedition.org/ejas/15111

DOI: 10.4000/ejas. 15111

ISSN: 1991-9336

Publisher

European Association for American Studies

Electronic reference

Adeline Chevrier-Bosseau, "Feline Alter Egos in Harriet Prescott Spofford's "Circumstance" and the Poetry of Emily Dickinson", European journal of American studies [Online], 14-3 | 2019, Online since 29 October 2019, connection on 08 July 2021. URL: http://journals.openedition.org/ejas/15111 ; DOI: https://doi.org/10.4000/ejas. 15111

This text was automatically generated on 8 July 2021.

Creative Commons License 


\title{
Feline Alter Egos in Harriet Prescott Spofford's "Circumstance" and the Poetry of Emily Dickinson
}

\author{
Adeline Chevrier-Bosseau
}

1 When she read it in the copy of The Atlantic Monthly her sister-in-law and lifelong friend Susan had lent her, Emily Dickinson was much impressed by Harriet Prescott Spofford's "Circumstance," as Sue recalls in her own review of Spofford's work entitled "Harriet Prescott's Early Work," in which she explains that upon reading the short story, Emily Dickinson asked her to "send [her] everything she writes." Both women were involved in an intense literary dialogue which went on until Dickinson's death. Through both letters and personal conversations, they discussed contemporary literary production, including Dickinson's own ongoing writing. Susan's reminiscence allows us to think that both women must have read Spofford's works extensively, and that they respected her as a writer. Adopting the characteristic-and ironic-pupil persona that she maintained throughout her correspondence with him, Dickinson's amusing reference to Spofford's short story in a letter written to Thomas Wentworth Higginson two years after its publication would mislead us to believe she did not follow Spofford's works so closely: 'I read Mrs Spofford's 'Circumstance,' but it followed me, in the Dark-so I avoided her-" (L261 to Thomas Wentworth Higginson, April 25, 1862). Reading beyond the frightened little girl persona's discourse, what is extremely noticeable in this comment is that Dickinson clearly dissociates the writer, designated by the female pronoun "her," from her "creature," the Indian Devil or the story, designated by "it"; the creature, the woman's creation, appears as the scariest element of all. Dickinson thus alludes here to the trope of the monstrous creation by the female writer, and to the combination of fear and awe that this creation elicits-a theme that is quite recurrent in her work, if we think for example about her reference to Elizabeth Barrett Browning's poetry in poem F627 "I think I was enchanted":

I think I was enchanted

When first a somber Girl - 
I read that Foreign Lady -

The Dark - felt beautiful -

Despite her claim that she "avoided" Spofford, her discussion with Susan attests to the allure of the "Dark" for the poetess, and to a sense of awareness-or self-awareness-of the monstrosity of female creation, be it incarnated by the monstrous creature (in Spofford's story, the Indian Devil is part-puma, part-dragon, part-snake ${ }^{3}$ and every bit as monstrous as Mary Shelley's creature) or the woman writer's monstrous creation (a fantastic tale dealing with hidden desires and fears). Analyzing the complex relationship of female writers to authorship, the authors of The Madwoman in the Attic choose Lilith as the figure who best associates female authorship and this anxiety of monstrosity, of abnormality: "both the first woman and the first monster [Lilith] specifically connects poetic presumption with madness, freakishness, monstrosity" (Gilbert and Gubar 35). Dickinson's contradictory allusions to Spofford illustrate how difficult it was for women writers to come to terms with this anxiety of authorship, and to comply with society's injunctions: Dickinson could admire Spofford in the private sphere of her correspondence with Sue, but she had to appear as a frightened little girl to Higginson if she wanted to have a chance at publication. ${ }^{4}$

Drawing on the initial ambiguity of the combination of admiration and fear that is apparent in Dickinson's references to "Circumstance," the contrast between the allure of the dark and the proclaimed fear of the dark, between a woman writer's artistic ambition and her society's injunctions, this paper will focus on felines in Spofford's "Circumstance" and a cluster of Dickinson's poems in which the feline, a creature of horror, appears as an alter ego of the woman writer. As in the examples of monstrous females gathered together by Gilbert and Gubar, the "feline" becomes a composite image, conflating the characteristics of the domestic cat, wild felines like pumas or tigers, and the snake or the dragon-therefore making the feline a nodal figure articulating discourses on female authorship, the anxiety of feeling "other," and a discourse of resistance to a stifling patriarchal culture. In Spofford's short story and Dickinson's feline poems, a specular inversion between the self and the feline brings the creator to reflect upon her status as a female writer in nineteenth-century America, between the mainstream and unthreatening image of the strange poetess or the gentle -albeit "half-cracked"-artist inscribed in nineteenth-century sentimental culture and her deep-rooted feeling of precariousness as well as her protean capacity for identification in a literary culture in which women had to comply with certain prescribed standards to be published. ${ }^{5}$ The feline, at once me and not-me, becomes for both women a figure onto which they project anxieties about female desire, female power and aggressiveness, about the association of femininity with animality, as well as about racial otherness. After replacing the identification with the feline within nineteenth-century scientific discourses and sentimental culture, this paper will explore the racial and political dimension of the animal identification in both women's works. 


\section{1. "A Dying Tiger - moaned for Drink / I hunted all the Sand": Women and Animals in Nineteenth-century Sentimental Culture}

4 As Keith Thomas' study Man and the Natural World has shown, the shift in the perception of animals-initiated with the publication of biological taxonomies such as those of Buffon highlighting similarities between human and animal anatomy-widened in the nineteenth century. As pet keeping became more and more popular, the awareness of physical and psychological likenesses between humans and animals increased; animals were still considered as "other," but it was acknowledged that they could have feelings of pain or joy, for instance, as humans did and therefore deserved compassion. Compassion for animals was highly valued during the Victorian era. ${ }^{6}$ A series of Acts of Parliament were adopted against cruelty for animals (Thomas 149) and movements promoting animal rights, including vegetarianism, began to spread in America (Thomas 295-296). In Humans and Other Animals: Beyond the Boundaries of Anthropology, Barbara Noske highlights a crucial difference in the perception of animality according to gender: "In as far as humanness is equated with the shaping of culture and history, men are made to appear more human than women. Women are commonly thought of as more biological than cultural, and are taken to be closer to animals than men" (Noske 40).

5 Noske further remarks that the qualities of "empathy, intersubjectivity and relatedness" (40) exhibited by women were the qualities that brought them closer to the animal realm than men. In an 1887 article published in Harper's Monthly Magazine, Thomas Wentworth Higginson explores this particular affinity between women and animals and compares "the care given by the young girl" to her pet to the "tenderness of a mother to her child." In Higginson's representation, pet-keeping and pet care is practice for motherhood, and similar in terms of the care and affection bestowed on the smaller being by the woman. Such a representation, as Colleen Gleeney Boggs notes, "anthropomorphizes animals and animalizes children" (205). Children, women and animals thus form a group united by their weaker intellect, their heightened capacity to feel rather than think, and their subjection to man. ${ }^{7}$ This natural connection between women and animals is perceptible in Spofford's "Circumstance" and Dickinson's "tiger" poems, in which the female character or speaker displays a capacity for immediate understanding of the animal's behavior. As Brigitte Nicole Fielder reminds us, nineteenth-century taxonomies also established a hierarchy between races, not only between species: "for nineteenth-century American readers, popular understandings of race were informed by theories of scientific racism, which rendered race and species never fully extricable from each other" (Fielder 490-491). A combination of the cat, the tiger, the snake and even the dragon, the feline is also racially other. The "Indian Devil," as it is called, stands out as a racially composite image, conflating the figure of the black slave, the "Indian," and an Orientalist self.

6 As we will see, both texts also integrate anxieties about animal assimilation-which have a particular resonance for women in many respects. In his chapter entitled "Maintaining the Boundaries," Keith Thomas explores the anxieties about "any form of behavior which threaten[s] to transgress the fragile boundaries between man and the animal creation" (Thomas 38); according to Thomas, notions like "bestiality" or 
“animality," pointing to the animal's lack of restraint, ferocity and savage impulses, are in fact man's projections of his own dark impulses on the animal:

Men attributed to animals the natural impulses they most feared in themselvesferocity, gluttony, sexuality-even though it was men, not beasts, who made war on their own species, ate more than was good for them and were sexually active all the year round. It was as a comment on human nature that the concept of 'animality' was devised. (Thomas 40-41)

7 As pure "Angels in the House" in Victorian sentimental culture, women supposedly rose above the bestiality of men, and elevated their male counterparts to higher levels of virtue. Judith Fetterley suggests that

Like Lydia Sigourney's 'The Father' and Harriet Beecher Stowe's The Pearl of Orr's Island, 'Circumstance' dramatizes the nineteenth-century conviction that men, despite their lower nature, have a spiritual component that responds to women and by means of which women can tame their beast and raise them to a higher level. (Fetterley 266)

In "Circumstance" as in the poems by Emily Dickinson, the female character or speaker is able to work with and even tone down the animal's "bestiality" and make the feline less harmful, less savage, if not harmless. The association made by Higginson between caring for children and caring for pets is apparent in Spofford's short story, in which the "Indian Devil" is soothed, like a baby, by the woman's song: "she had heard that music charmed wild beasts ... and when she opened her lips the third time, it was not for shrieking, but for singing. A little thread of melody stole out, a rill of tremulous motion; it was the cradle-song with which she rocked her baby" (158).

Despite the terror he generates, the "Indian Devil" behaves overall like an overgrown kitten: a wild feline would go directly for the kill and then consume its prey, but the well-fed domesticated cat usually plays with the mice it catches before eating themlike the "Indian Devil" does in the short story. The fact that the beast does not immediately tear her flesh to shreds but toys with her points to its perversityemphasized by the use of the adverb "sagaciously" to refer to the movement of its claws-but also to its kinship with domestic cats. Like the pet cat, the puma kneads its paws ("he worried them sagaciously a little," "fretted the imprisoned claws," 159)-a movement that is usually accompanied by purring, and that reveals the animal's comfort and satisfaction before finding a suitable spot and position to rest in-which the puma finally does, "lay[ing] the disengaged paw across her with heavy satisfaction" (160). Like the domestic cat, the "Indian Devil" sharpens its claws on the bark of a tree: "the creature who grasped her uncurled his paw and scratched the bark from the bough" (160). The cat's rough licking of the woman's arm and face can also recall the actions of a mother cat with her kitten, and the movement of its head and facial expression at times are extremely reminiscent of a cat ("he fawned his fearful head upon her," 163, "he half closed his eyes, and sleepily reopened and shut them again," 162) or a dog ("the beast made a sluggish movement,--stretched and fawned like one awakening,-then, as if he would have yet more of the enchantment, stirred her slightly with his muzzle," 171) with its mistress. The understanding and anticipation of the puma's behavior displayed by the female character is enabled by the beast's comparison to a pet: since women are naturally sympathetic to animals and affectionate to their pets, the female character in "Circumstance" seems to understand naturally, despite her terror and disgust, how the beast's mind works, and how to offer it something it will like (the song) to get what she wants from the puma. Her survival is 
due to her ethological skills, her understanding of the beast, and her capacity to tame it: the woman's natural capacity to understand how to interact with the animal and the construction of the puma's behavior modeled on the behavior of domesticated pets echo the relations to animals in nineteenth-century sentimental culture and the representations of women as naturally connected-emotionally and instinctively-to the animal world. If women were naturally sympathetic to "innocent" animals, they were also more likely to naturally empathize with the suffering slave-as Fielder has shown in her study of animal comparisons in the abolitionist discourse. Indeed, as Fielder reminds us in her analysis of Mrs. Bird's defense of the kitten and Eliza in Uncle Tom's Cabin, antislavery and animal welfare movements were connected in nineteenthcentury America (Fielder 494).

In Dickinson's poem "A Dying tiger - moaned for drink", the speaker is less in danger in front of the feline, because the tiger is dying, and therefore relatively innocuous:

A Dying Tiger - moaned for Drink -

I hunted all the Sand -

I caught the Dripping of a Rock

And bore it in my Hand -

His mighty Balls - in death were thick -

But searching - I could see

A Vision on the Retina

of Water - and of me -

'Twas not my blame - who sped too slow -

'Twas not his blame - who died

While I was reaching him -

But "twas - the fact that He was dead - (F529)

11 Like Spofford in "Circumstance," Dickinson uses the pronoun "he" while referring to the tiger, not "it," another sign of the humanization of the animal. Here the female speaker shows Christian mercy to the tiger by attempting to bring him water in his final moments ("I hunted all the Sand - / I caught the Dripping of a Rock / And bore it in my Hand"); the speaker "hunt[s]" not the tiger, but the water that can save him. We get a fleeting glimpse of a possible tragic outcome for the female speaker, the hunterturned-prey, in the "Vision on the Retina / Of Water - and of me" of the tiger, when the two edible objects, the woman and the water, are reflected in his death-glazed eyes. The affinity between the female speaker and the wild feline is here emphasized by the specular inversion: in this respect, the use of the terms "A vision on the retina" is extremely accurate scientifically, and operates a shift in the perspective, where the animal and the woman are no longer two, but one and the same. Dickinson was very interested in science and, having herself suffered from a debilitating eye condition (Sewall xxiv ), probably knew a lot about eye pathologies and how the human eye works. Here Dickinson correctly locates the site of vision in the retina, which is the rear part of the eye, the one which is connected to neurons and which transmits the received information to the brain. The fact that the image is received by the retina is interesting in this sense, because the cornea and lens send an inverted image to the retina, which then processes the information. Here the vision of herself in the tiger's retina therefore enacts this specular inversion. The speaker does not merely see herself through the tiger's eyes but sees herself in the tiger, within the beast. We can therefore wonder if what the speaker "searches" ("searching - I could see," 1. 6) in the depths of 
the tiger's eyes is not ultimately herself. Imbued by nineteenth-century discourses on the natural affinity between women and the animal world, the woman writer questions her legitimacy to claim an identification with culture rather than nature, to challenge the patriarchal dichotomy (man-culture / woman-nature), in her complex identification with and dissociation from the animal. As Anne Dalke has shown in her article "'Circumstance' and the Creative Woman: Harriet Prescott Spofford," the woman acknowledges her kinship to the beast, and "rises above" this base condition through the act of artistic creation:

Walking on the edge of the woods, at the edge of evening, this young woman slips over the margin and encounters her own worst self in the forest. She fights in the dark woods not something other, but her own lower nature .... The protagonist of Spofford's story succeeds in subduing that lower self, by rising above it. Much is made of the fetid smell of the breath of the beast, but this young woman makes more of her own exhalations. She puts down the base self by developing, suddenly, on penalty of death, the higher one: she becomes imaginative, creative. (Dalke 76-77)

In Spofford's and Dickinson's writings, the feline is an alter ego of the woman writer as well as the image of an abject "other" the woman writer acknowledges is like her but wishes he was not so much like her, in an ambiguous dynamics of identification which reflects the patriarchal injunctions that the woman writer had to grapple with, as well as the complexity of the protean dimension of the figure of the female creator-partmonster, part-creator.

\section{2. "I knew a Bird that would sing as firm in the center of Dissolution, as in its Father's nest - "8: The Woman Writer Singing from the "center of Dissolution"}

13 As Anne Dalke delineates, comparing "Circumstance" to Kate Chopin's "Désirée's Baby," Spofford's short story is "a tale about the uncertain margins of existence" (Dalke 74), and the liminal setting-the forest-is, just like in Shakespeare's A Midsummer Night's Dream or As You Like It, a world on the edge of rational, patriarchal society where all the inversions and subversions become possible for the female protagonist. Dalke adds that time is liminal as well in "Circumstance" ("it is set, as well, at a marginal time," Dalke 75), in the late hours of the day, between daylight and sunset, "on the edge of the evening" (Spofford 156). In Emily Dickinson's poem "A Dying Tiger - moaned for Drink", the space where the speaker evolves is also a limbic space, some sort of desert-which could be in Africa, Asia, or the deserts and wilderness of the American Frontier-as we can picture from the reference to the "sand" (1.2) and the "rock" (1. 3). The following poem featuring a tiger also unfolds in a limbic, imaginary space, between the sea (1. 1), the "lonely Valleys" (l. 3) and some exotic, foreign place ("Dates and Cocoa," 1. 11, "Domingo," 1. 15):

As the Starved Maelstrom laps the Navies

As the Vulture teased

Forces the Broods in lonely Valleys

As the Tiger eased

By but a Crumb of Blood, fasts Scarlet

Till he meet a Man

Dainty adorned with Veins and Tissues 


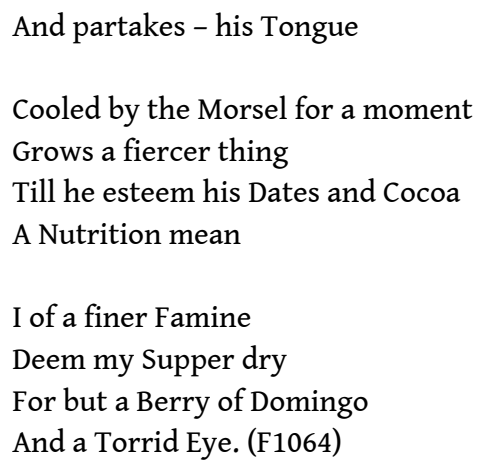

14 The reference to these exotic, limbic spaces "exoticizes" the feline and emphasizes the racial conflation, by associating the beast with Africa, the Caribbean and Asia. "As the Starved Maelstrom laps the Navies" associates the figure of the feline with the themes of want and starvation, with the delayed satisfaction of appetite, and with the violence of the frustration experienced by both the speaker and the feline. The speaker's appetite and the feline's are closely connected throughout the poem (via the use of "as" repeated three times in the first stanza and the comparative "finer" in the last one), but although the speaker claims that, as in Spofford's short story, she rises above the low impulses of the beast, the satisfaction of her hunger will be as violent as the tiger's. The reference to a "Crumb of Blood," conveying the image of coagulated, solidified blood, associates blood with bread, the tiger's nourishment with the human speaker's. Just as we can anticipate the bloodbath that will ensue when the tiger digs his teeth into the "dainty" assemblage of delicate "veins and tissues" of the skinned body of the "man", we can picture the red juice on the speaker's lips when she bites into the "Berry of Domingo." The image of the "Torrid Eye" animalizes the speaker, the "torrid I," whose lustful eyes burn with unsatisfied desire, like the tiger's. The tiger's-and the speaker's-vision undresses and skins the human prey, since the poem offers us the vision of a skinned body, "Dainty adorned with veins and tissues." In Spofford's "Circumstance," the "Indian Devil"-like the tiger in this poem"-exercises a certain degree of restraint, since he does not devour his prey right away, like any predator would. In fact, he does not seem that interested in eating the woman, and seems to derive from the encounter an affective and almost artistic satisfaction rather than the satisfaction of pure hunger:

It might be that he was not greatly famished; for, as she suddenly flung up her voice again, he settled himself composedly on the bough, still clasping her with invincible pressure to his rough, ravenous breast, and listening in a fascination to the sad, strange U-la-lu that now moaned forth in loud, hollow tones above him. He half closed his eyes, and sleepily reopened and shut them again. (161-162)

The feline seems "ravenous" for the song rather than for the woman's flesh. In fact, the flesh eating occurs only in the woman's imagination:

What rending pains were close at hand! Death! and what a death! worse than any other that is to be named! .... No gnawing disease can bring such hideous end as this; for that is a fiend bred of your own flesh, and this-is it a fiend, this living lump of appetites? What dread comes with the thought of perishing in flames! but fire, let it leap and hiss never so hotly, is something too remote, too alien, to inspire us with such loathly horror as a wild beast; if it have a life, that life is too utterly beyond our comprehension. Fire is not half ourselves; as it devours, arouses neither hatred nor disgust; is not to be known by the strength of our lower natures let loose; does not drip our blood into our faces from foaming chaps, nor mouth nor slaver above us with vitality. Let us be ended by fire, and we are ashes, for the 
winds to bear, the leaves to cover; let us be ended by wild beasts, and the base, cursed thing howls with us forever through the forest. (162) the speaker's consciousness, and not actually done by the animal. This capacity for empathy with the beast and the importance given to the sensual pleasure experienced by the animal overshadows the pain of the human body which will be torn apart and eaten. The desire of the feline and that of the female speaker are superposed. In Spofford's text, the narrator insists on the beast's sensual enjoyment of the songs, and the sensual pleasure he would derive from eating her-conveyed through the insistence on the beast's salivating mouth, or salivating gaze: "the beast threw back his head so that the diabolical face fronted hers, and the torrent of his breath prepared her for his feast as the anaconda slimes his prey" (160). There is a form of consummation by proxy, of delayed satisfaction, of longing whetted by restraint and self-inflicted frustration in this projection of the beast's sensuality, which seems to me quite similar to the shared experience of frustration in Dickinson's “tiger" poems. In Dickinson's poem, the "finer famine" of the lyric self is appeased by a poetic feast rather than by actual food contrary to the tiger, but both experience a common "torrid" longing. The wilderness's liminality and transformative powers enable the woman to revert to a form of limbic psychological topography. She recognizes her animal instincts, the base animality she has evolved from but which she acknowledges all the same as her point of origin. In that sense, the woman writer's representation of the racialized feline echoes the discourse of nineteenth-century taxonomies, and establishes a filiation which asserts both an evolution from and a kinship with other races and species.

In the opening stanzas of this poem, the dialectic of starvation and consumption is again articulated through the comparison with the feline:

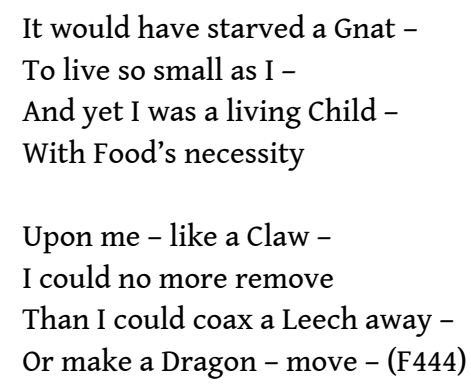

Here the feline is represented metonymically through the "claw" restricting the speaker. The association of the feline with a blood-sucking leech or a dragon is reminiscent of Spofford's "fabulous flying-dragon," as is the position of the claw "upon" the self, preventing her from moving, which reminds us of the positioning of the Indian Devil's paw "across" the woman (160). The composite figure of the feline (cat, tiger, dragon, serpent) functions as a metaphor for the basest impulses of any living being (eating, drinking), which restricts the speaker and prevents her from achieving a state of complete liberation from the body's necessities. The speaker, just like in the previous poem, proclaims an ascetic refusal of greed (or even the simple satisfaction of hunger) and longs for a life free from "food's necessity," for spiritual or literary nourishment perhaps, and in any case for metaphorical nourishment that would remove her from her "lower self," from base animal instincts; but she still has to eat ... The speaker is powerless in front of her own animal instincts: no "coaxing" will stop the "leech," "dragon," or feline of hunger from sinking its fangs into her being and thoroughly possessing her. 
image of the "Maelstrom" used in the first poem also appears in "Twas like a Maelstrom, with a notch" (F425), which Maryanne Garbowsky compellingly connects with Harriet Prescott Spofford's "Circumstance": in this poem such as in "As the Starved Maelstrom laps the Navies," the "Maelstrom" is a vortex, a whirlpool that threatens to absorb the female figure, which we can read as the threat of the animal regression which will reassimilate the woman into nature and cut her off completely from culture and civilization. A "Maelstrom" also signifies a jumble, a confusion of feelings. In Spofford's text as in Dickinson's poems, the female voices are definitely entangled in contradictions, between complying with a sentimental culture in which women are more naturally sympathetic to the weakest (animals, children, and, since they were often animalized in nineteenth-century discourse, people of color) and the reluctance to be assimilated to beings they deem inferior, which threatens to sever their ties to culture and might lead them to be reintegrated into nature. In this literary maelstrom, issues like gender, anxieties about authorship and assimilation with nature, as well as racial anxieties are intricately entangled. In both women writers' works, the feline is associated with racial otherness. This is very obvious in the use of the name "Indian Devil" in Spofford's "Circumstance" to designate what is most likely a puma, and in Dickinson's "As the Starved Maelstrom laps the Navies," the representation of the tiger and the image of the "Berry of Domingo" in the last stanza are clearly laden with racial meaning. As Cristanne Miller has argued in Reading in Time, Emily Dickinson in the Nineteenth Century, Dickinson frequently uses the term "berry" to refer to AfricanAmericans (see Miller 13-17). In her reading of this poem, Eliza Richards points out the ambiguity of the image of the suffering tiger, which elicits both sympathy and a desire to differentiate herself from him on the part of the speaker. If, according to Richards, the tiger symbolizes "African-American rage" (Richards 171-174) as well as the suffering of slaves, the ambiguity of the white speaker is evident: as in the case of the poems featuring felines or Spofford's "Circumstance," the racialized feline is both an object of compassion and of fear. In Thomas De Quincey's Confessions of an English OpiumEater, the famous "Malay" that unexpectedly shows up at the protagonist's house is compared to a "tiger-cat," in another conflation of the feline species (De Quincey 56). In this poem by Emily Dickinson, the figure of the "Malay" and the dynamics of reversibility at work in the poem are very reminiscent of Dickinson's "tiger" poems:

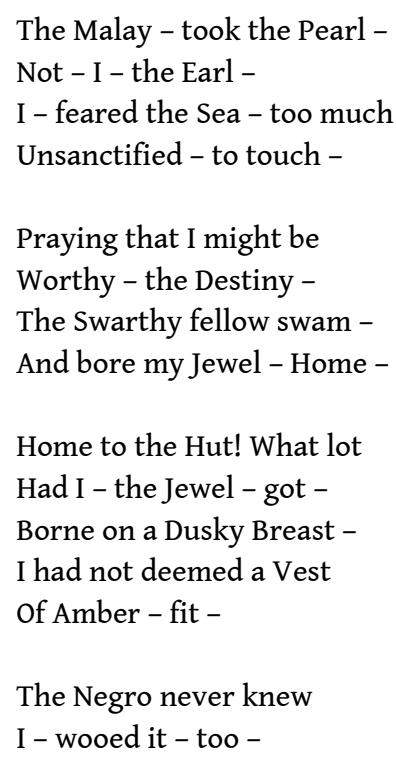


To gain, or be undone -

Alike to Him - One - (F451)

20 poem is predatory: the Malay "takes" the "Pearl" away to its den ("The Swarthy fellow swam - And bore my Jewel - Home"), while the white speaker, identified as an "Earl" in the second line, watches, unable to intervene. The object of desire is the same for the white speaker and the dark other, who both want to possess the "Pearl," the white woman. This common desire is comparable to the community of desire in the "tiger" poems, as is the ambiguity in the identification with the "other"-be it animal or human. Indeed, the white speaker opposes his nobility and restraint (1. 2-4) to the dark other's brutal actions: while the Malay is deemed "[un]fit" (1. 12-13) to possess the precious "Jewel" and is feared by the speaker, the latter also seems to long for his capacity for action and fearlessness. For the reader, this association between animals and dark others in Spofford and Dickinson's works is disturbing, since it echoes contemporary racist discourses equating African-Americans to animals and presenting them as beasts incapable of intellect or restraint-especially when white women are involved. This animal association is also to be read in the light of nineteenth-century sentimental discourse, in which African-American slaves, who are treated like animals and denied any humanity by the white masters who torture them, are the object of Christian sympathy in Beecher Stowe's Uncle Tom's Cabin and the abolitionist literary production issued in the wake of Stowe's famous novel. In this configuration, white women are both the victims of choice of the beastly dark other as well as those who can best empathize with them because of their natural propensity to sympathize and care for the weakest (children, oppressed people and animals), being part of "the weaker sex" themselves.

21 What is striking in both women's works is the way these authors negotiate these contemporary discourses while managing somehow to challenge the domination of white masculinity. In Emily Dickinson's “The Malay - took the Pearl," white masculinity literally pales in comparison to the dark other's capacity for action and fearlessness. Another way that white masculinity is undermined in this poem is through what Páraic Finnerty characterizes as "cross-dressing." In his analysis of this poem, Finnerty states that "Dickinson's Earl is a gender-blurring speaker rather than a silent authoritative male" (Finnerty 81), and he adds that such cross-dressing "reflect[s] Dickinson's need as a woman who conformed to her culture's ideals of femininity and was almost 'parodically female ${ }^{10}$ ' to unsettle and obscure, in her poems, nineteenth-century gender arrangements" (Finnerty 66). As Judith Fetterley notes, traditional gender roles are also unsettled in Spofford's "Circumstance":

much of the strength of 'Circumstance' derives from Spofford's success in finding a mechanism for presenting a woman outside the home. As if to emphasize her strategy, Spofford presents in detail her protagonist's visions of her husband, safe at home, tending the hearth, soothing the child. He, not she, is domestic, and she, not he, is out in the world, exposed to the hard fact of real danger. (Fetterley 265)

Both women writers therefore create subversive female figures, grappling not only with wild felines but with multiple patriarchal snares. Spofford's and Dickinson's construction of the wild feline is enmeshed in nineteenth-century discourses of white male domination, in which women, children, people of color and animals are all subjected to white masculinity. In this context, the racialized feline is, for the female self struggling to find her voice amidst the maelstrom, both a figure of abjection and an 
indissociable alter ego-a construction that echoes what Toni Morrison delineates in her seminal essay Playing in the Dark, Whiteness and the Literary Imagination. According to Morrison,

For the settlers and for American writers generally, this Africanist other became the means of thinking about body, mind, chaos, kindness, and love; provided the occasion for exercises in the absence of restraint, the presence of restraint, the contemplation of freedom and of aggression; permitted opportunities for the exploration of ethics and morality, for meeting the obligations of the social contract, for bearing the cross of religion and following out the ramifications of power. (47-48) Africanist other, as a projection of the woman writer's darkest instincts and fearssexuality, freedom from the considerable restraints weighing on women, sexual and racial anxieties, etc. It is particularly obvious in both women's works that the feline provides, in Morrison's words, "the occasion for exercises in the absence of restraint, the presence of restraint." A reading of both texts as echoing the abolitionist debateas Michael Grimwood has done in his article on "Circumstance"11-is of course perfectly germane, but when focusing on the role and symbolism of the feline alter ego in both women's texts, the way these two female writers grapple with structures of domination appears infinitely more complex. As well-to-do white women, Dickinson and Spofford were themselves part of the dominant caste. In Dickinson's "tiger" poems as well as in Spofford's "Circumstance," the figure of the feline crystallizes the ambiguity of the women's position in struggles challenging white male domination, between a natural affinity with the dominated, suffering ones, and deep anxieties about being reassimilated into nature and losing the privilege of the affiliation to culture. In a letter written to Mrs. Holland in 1881, Dickinson refers to "a Bird that would sing as firm in the center of Dissolution, as in its Father's nest - Phenix, or the Robin"; it appears that both Spofford's and Dickinson's female voices sing from this nest of patriarchal snares, from the maelstrom, from the "center of dissolution," thus showcasing the complexity, elusiveness and protean capacity of identification of female voices in the nineteenthcentury American literary landscape.

\section{BIBLIOGRAPHY}

Baker, Steve. Picturing the Beast: Animals, Identity and Representation. Manchester: Manchester UP, 1993.

Bennett, Paula. "'Pomegranate-Flowers': The Phantasmic Productions of Late-NineteenthCentury Anglo-American Women Poets." Solitary Pleasures: The Historical, Literary, and Artistic Discourses of Autoeroticism. Eds. Paula Bennett and Vernon A. Rosario. New York: Routledge, 1995. 189-213.

Berger, John. Why Look at Animals? London: Penguin, 2009. 
Birke, Lynda. "Supporting the Underdog: Feminism, Animal Rights and Citizenship in the Work of Alice Morgan Wright and Edith Goode.” Women's History Review 9.4 (2000): 693-719.

Boyd, Anne E. "What! Has she got into the Atlantic? Women Writers, the Atlantic Monthly, and the Formation of the American Canon." American Studies 39.3 (1998): 5-36.

Dalke, Anne. “'Circumstance' and the Creative Woman: Harriet Prescott Spofford.” Arizona Quarterly: A Journal of American Literature, Culture, and Theory 41.1 (1985): 71-85.

De Quincey, Thomas. Confessions of an English Opium-Eater. Oxford: Oxford World Classics, 1998.

Dickinson, Emily. The Poems of Emily Dickinson. Ed. Ralph W. Franklin. Variorum Edition. 3 volumes. Cambridge, MA: The Belknap Press of Harvard UP, 1998.

---. The Letters of Emily Dickinson. Eds. Thomas H. Johnson and Theodora Ward. Cambridge, MA: The Belknap Press of Harvard UP, 1958.

Ellis, R. J. “'Latent Color' and 'Exaggerated Snow': Whiteness and Race in Harriet Prescott Spofford's 'The Amber Gods'.” Journal of American Studies 40.2 (2006): 257-82.

Fetterley, Judith. "Harriet Prescott Spofford, Circumstance." Provisions, A Reader from $19^{\text {th }}$ Century American Women. Bloomington: Indiana UP, 1985. 261-278.

Fielder, Brigitte Nicole. "Animal Humanism: Race, Species, and Affective Kinship in NineteenthCentury Abolitionism.” American Quarterly 65.3 (2013): 487-514.

Finnerty, Páraic. ““"No Matter - now - Sweet - But when I'm Earl”: Dickinson's Shakespearean Cross-Dressing." The Emily Dickinson Journal 7.2 (1998): 65-94.

Folsom, Ed, and Kenneth M. Price. "Emily Dickinson, Slavery, and the San Domingo Moment." University of Nebraska-Lincoln. http://www.unl.edu/Price/dickinson/

Garbowsky, Maryanne M. “A Maternal Muse for Emily Dickinson.” Dickinson Studies: Emily Dickinson (1830-86), U.S. Poet 41 (1981): 12-17.

Gaul, Theresa Strouth. "Captivity, Childbirth, and the Civil War in Harriet Prescott Spofford's “Circumstance.” Legacy: A Journal of American Women Writers 19.1 (2002): 35-43.

Gilbert, Sandra M., and Gubar, Susan. The Madwoman in the Attic, The Woman Writer and the Nineteenth-Century Literary Imagination. New Haven and London: Yale UP, 2000 [1979].

Glenney-Boggs, Colleen. "Animals and the Formation of Liberal Subjectivity in NineteenthCentury American Literature." The Oxford Handbook of Nineteenth-Century American Literature. Ed. Ruth Castronovo. Oxford: Oxford UP, 2012: 197-216.

Grimwood, Michael. “'Circumstance' in 1860.” ESQ: A Journal of the American Renaissance 58.4 (2012): 447-492.

Higginson, Thomas Wentworth. “Women and Men: Children and Animals." Harper's New Monthly, July 1887.

Holly, Carol. “'Grand and Sweet Methodist Hymns': Spiritual Transformation and Imperialistic Vision in Harriet Prescott Spofford's 'Circumstance.”' Legacy: A Journal of American Women Writers 18.2 (2001): 153-166.

Ingold, Tim. What Is An Animal? London: Unwin Hyman, 1988.

Kenyon-Jones, Christine. Kindred Brutes: Animals in Romantic-Period Writing. Aldershot: Ashgate, 2001. 
Marshall, Ian. "Literal and Metaphoric Harmony with Nature: Ecofeminism and Harriet Prescott Spofford's 'Circumstance.”' Modern Language Studies 23.2 (1993): 48-58.

McAbee, Leslie. “Through the Tiger's Eye: Constructing Animal Exoticism in Emily Dickinson's 'Big Cat' Poems." The Emily Dickinson Journal 26.1 (2017): 1-26.

Miller, Cristanne. Reading in Time, Emily Dickinson in the Nineteenth Century. Amherst: U of Massachusetts P, 2012.

Morrison, Toni. Playing in the Dark, Whiteness and the Literary Imagination. New York: Vintage Books, 1993.

Noske, Barbara. Humans and Other Animals: Beyond the Boundaries of Anthropology. London: Pluto Press, 1989.

Richards, Eliza. “'How News Must feel When Travelling': Dickinson and Civil War Media.” Companion to Emily Dickinson's Poetry. Eds. M. N. Smith \& M. Loeffelholz. London: Blackwell, 2007. 157-79.

Saint Armand, Barton Levi. Emily Dickinson and Her Culture: The Soul's Society, Cambridge: Cambridge UP, 1984.

Sewall, Richard. The Life of Emily Dickinson. Cambridge, MA: Harvard UP, 1974.

Sivils, Matthew. “'The Base, Cursed Thing': Panther Attacks, Ecotones, and Antebellum American Fiction.” The Journal of Ecocriticism 2.1 (2010): 19-32.

Spengler, Birgit. "Gendered Vision(s) in the Short Fiction of Harriet Prescott Spofford." Legacy: A Journal of American Women Writers 21.1 (2004): 68-73.

Spofford, Harriet Elizabeth (Prescott). "Circumstance." The Amber Gods and Other Stories. Freeport, New York: Books for Libraries Press, 1969 [1863]. 153-172.

Thomas, Keith. Man and the Natural World: A History of the Modern Sensibility. New York: Pantheon Books, 1983.

\section{NOTES}

1. Susan Dickinson's "Harriet Prescott's Early Work" was addressed to the editor of The Republican in January 1903 and is available on the Dickinson electronic archives: http:// archive.emilydickinson.org/susan/tshdcpb31.html

2. Marianne Garbowsky also makes this distinction when she specifies "it was the spectre of the Indian Devil which took hold of Dickinson's imagination and 'followed' her 'in the Dark"' and that "the beast must have terrorized Emily Dickinson, lingering in her psyche for months, roaming freely through her imagination" (Garbowsky 13).

3. As we can see in the series of examples of female monstrosity compiled by Gilbert and Gubar, the female monster-from Thackeray to Spenser-often combines the characteristics of snakes, felines and dragons, thus becoming a slithering, ferocious and treacherous creature endowed with fangs and claws (Gilbert and Gubar 29-36).

4. Dickinson's performance of the bashful, timid and "half-cracked poetess," as Higginson used to call her, was not enough however to make him forget the unpublishability of her "spasmodic gait" (L265).

5. In this respect, T. W. Higginson is an important figure: as both women's "mentor," he gave them advice and was influential in the publication of their work, often shaping them to what he perceived was appropriately publishable-especially in the case of Dickinson. 
6. Keith Thomas notes that "in her Jubilee address of 1887 Queen Victoria would comment that 'among other marks of the spread of enlightenment amongst my subjects' she had noticed in particular, 'with real pleasure, the growth of more humane feelings towards the lower animals"' (Thomas 149-150).

7. As Lynda Birke delineates in her article "Supporting the Underdog: Feminism, Animal Rights and Citizenship in the Work of Alice Morgan Wright and Edith Goode," women were particularly active in the defense of animal rights in the nineteenth century, since "women and non-human animals [were] seen as similarly subject to interconnected systems of domination, which posit both women and animals as inferior" (Birke 693).

8. L685 to Mrs. Holland, January 1881.

9. In her study of this poem in her article "Through the Tiger's Eye: Constructing Animal Exoticism in Emily Dickinson's 'Big Cat' Poems," Leslie McAbee highlights the "gentlemanly" behavior of the tiger in Dickinson's poem: "this anthropomorphized Tiger is also a gentleman of refined etiquette who recognizes the aesthetic beauty of his supper so 'Dainty adorned.' He savors and contemplates his meal when he 'partakes - his Tongue' with protracted satisfaction and 'esteems' his food choices with thoughtful deliberation in spite of his fevered addiction" (McAbee 13).

10. The quote is from Sandra M. Gilbert, "The American Sexual Poetics of Walt Whitman and Emily Dickinson," Reconstructing American Literary History (ed. Sacvan Bercovitch, Cambridge, MA: Harvard UP, 1986), 123-154.

11. In this article, Grimwood explains that when Spofford wrote her short story, slavery was perceived as a dragon, as a serpent ensnaring the south (Grimwood 472), which accounts for the dynamics of entrapment, of ensnaring in the two women's texts. He adds that when reading the short story, Emily Dickinson would certainly have recognized the racial dimension in Spofford's discourse (479-481).

\section{ABSTRACTS}

This paper focuses on the role of the feline in Harriet Prescott Spofford's short story "Circumstance" and three poems by Emily Dickinson (F529, F444, and F1064). In these texts, the feline becomes an alter ego for the woman writer, leading her to reflect upon her status as a female artist in the nineteenth century in connection to the sentimental culture of the time and to issues such as race, violence and power. At once me and not-me, the feline is racialized in the two writers' works, and its function is akin to that of the "Africanist other" as defined by Toni Morrison in Playing in the Dark, Whiteness and the Literary Imagination. When the female self is in the claws of the feline, or compared to the feline, she grapples with multiple snares as her voice is entangled within the contradictory impulses she strives to negotiate. Singing from this nest of snares, the female voice that we hear in these texts showcases the complexity, elusiveness and protean capacity of identification of female writers in the nineteenth-century American literary landscape. 


\section{INDEX}

Keywords: Emily Dickinson, Harriet Prescott Spofford, felines, race, violence, power, American nineteenth-century sentimental culture

\section{AUTHOR}

\section{ADELINE CHEVRIER-BOSSEAU}

Adeline Chevrier-Bosseau is Associate Professor of American literature and Dance studies at the University of Clermont-Auvergne. She has published several articles examining the influence of Shakespearean theatricality on Emily Dickinson's poetry in French journals such as Transatlantica or Représentations, and in collective works such as Thy Truth Then Be Thy Dowry, Questions of Inheritance in American Women's Literature (ed. Stéphanie Durrans, Cambridge Scholars Publishing, 2014). Her book, Emily Dickinson du côté de Shakespeare: modalités théâtrales du lyrisme, is forthcoming at the Presses Universitaires Blaise Pascal (2020). Her current research focuses on the dialogue between American literature and dance, and she has recently published several papers on the place of dance in the poetry of Emily Dickinson and Walt Whitman. 